\title{
Opposition theory and computational semiotics
}

\author{
Dan Assaf \\ Independent researcher, Petach Tikva, Israel \\ Yochai Cohen \\ Gilasio Coding Ltd., Tel-Aviv, Israel \\ Marcel Danesi \\ University of Toronto, Toronto, Canada \\ Yair Neuman ${ }^{1}$ \\ Ben-Gurion University of the Negev, Israel \\ e-mail:yneuman@bgu.ac.il
}

\begin{abstract}
Opposition theory suggests that binary oppositions (e.g., high vs. low) underlie basic cognitive and linguistic processes. However, opposition theory has never been implemented in a computational cognitive-semiotics model. In this paper, we present a simple model of metaphor identification that relies on opposition theory. An algorithm instantiating the model has been tested on a data set of 100 phrases comprising adjectivenoun pairs in which approximately a half represent metaphorical language-use (e.g., dark thoughts) and the rest literal language-use (e.g., dark hair). The algorithm achieved $89 \%$ accuracy in metaphor identification and illustrates the relevance of opposition theory for modelling metaphor processing.
\end{abstract}

Keywords: opposition theory, computational semiotics, metaphor identification

Authors' names are presented alphabetically. Correspondence should be sent to Yair Neuman, Department of Education, Ben-Gurion University of the Negev, Beer-Sheva 8410501, Israel. 


\section{Introduction}

The idea that binary oppositions (i.e., contraries) stand at the heart of cognitive and linguistic processes is one of structuralism's basic tenets, which starts with the ideas of Ferdinand de Saussure (1916) (Danesi 2007). The criticism launched against this theory (Derrida 1967) mainly points at its shortcomings in explaining the complexity of human behaviour. Regardless of acknowledging the minimal explanatory power of opposition theory, one has to admit that there has not been a successful translation of this theory into a computational cognitive-semiotics model. We use the term 'computational' in the very limited sense of testing a model through computational tools and resources without obliging ourselves to a specific theory of mind. The importance of producing such a model is both in using the theory for addressing current scientific challenges and for providing some empirical support for the theory.

In this paper, we aim to address the above challenge by using opposition theory to design an algorithm for automatic metaphor identification, and to provide through the success of this algorithm some empirical support for the relevance of this theory that might be considered anachronistic in the contemporary era of "post-structuralist" ideologies.

The paper is organized as follows. We first provide a short introduction of opposition theory in its historical context. Next, we present the idea of metaphor and the challenge of automatic metaphor identification. This theoretical background is followed by a simple and novel model of metaphor identification and an algorithm that instantiates the model. Finally we provide an empirical test of the algorithm against a humanannotated dataset. We conclude by discussing an antiquarian approach seeking to revive old semiotic ideas through the use of modern tools of computational semantics.

\section{Opposition theory}

It was Saussure (1916) who first made opposition an inherent principle of linguistic structure, which he labeled différence. In the 1920s, the Prague School linguists (e.g., Jakobson et al. 1928; Trubetzkoy 1939) devised the first fully developed theory of opposition, which they used to carry out extensive analyses of specific natural languages. Opposition theory thus became synonymous with structuralism (Wallon 1945; Parsons, Bales 1955; Godel 1957; Lévi-Strauss 1958, 1971; Blanché 1966; Belardi 1970; Needham 1973; Ivanov 1974; Fox 1974, 1975; Lorrain 1975).

It must be noted that from a modern psychological perspective oppositions may be related to the fact that all well-defined categories must have a complement. That is, in order to identify a category the mind must distinguish members from non-members. This basic tenet of the mind may be the source of oppositions and will be further discussed in our model. 
The first in-depth psychological study of the validity of opposition was Ogden's classic treatise, Opposition: A Linguistic and Psychological Analysis (1932). Ogden expanded several key ideas he had discussed previously with I. A. Richards in The Meaning of Meaning (1923). For Ogden, a small set of conceptual oppositions, such as right/left and yes/no, were universal and intrinsically binary. Other (non-oppositional) concepts showed gradients as Bolinger (1968) later called them.

The technical framework for using opposition theory was developed by the Prague School and the Copenhagen School linguists (Hjelmslev 1939, 1959). Even within the generative framework of linguistic analyses, which pits itself against structuralism, this theory has been incorporated to carry out phonological analyses (Chomsky, Halle 1968; McCarthy 2001; Haspelmath 2006).

Starting in the 1980s, opposition theory was extended to encompass the study of all kinds of expressive phenomena, from discourse and narrative structure, to textuality and visual art (Barbaresi 1988; Mettinger 1994; Meľčuk 2001; Elšík, Matras 2006). The spread of Peircean (1931-1958) theory in the late 1960s into the mainstream of semiotic method, led initially to a de-emphasis of structuralist theory. However, Peircean theory was never antithetical to Prague School structuralism. On the contrary, as research has shown, Peircean semiotics and structuralism are highly compatible, or more precisely, complementary, models of semiosis (Andersen 1989, 2001, 2008; Tomic 1989). Completing the overall historical picture are the insights of the Tartu School semioticians under the leadership of Juri Lotman (cf. Lotman 1991), who utilized opposition theory to show how different cultural codes are interconnected to each other in oppositional ways (Andrews 2003; Lepik, 2008).

The Prague School linguists formalized the opposition in terms of the theory of distinctive features. For example, in the phonemic opposition /p/-vs.-/b/ ( pin/bin) the relevant differential feature is ( \pm voice), whereas in $/ \mathrm{b} /-\mathrm{vs.} . / \mathrm{m} /$ (beat $/$ meat) it is ( \pm nasal). Work on distinctive feature theory led, in turn, to a more comprehensive typology of oppositions (Trubetzkoy 1939), including: multidimensional, in which the distinctive features in one opposition occur in others; one-dimensional, in which the features in a specific opposition do not occur in others; isolated, in which the features that occur in specific oppositions, occur nowhere else in the system; proportional, in which the features constituting certain oppositions are repeated in others; privative, in which signs are distinguished by only one feature; gradual, which involves varying degrees of a feature; and equipollent, in which oppositions are distinguished by several features.

Applying distinctive-feature analysis to phonemic oppositions was a straightforward and largely unproblematic procedure. However, problems emerged when the same type of analysis was applied to conceptual oppositions. Pairs such as man-vs.-woman, boy-vs.-girl, for instance, could be easily distinguished in terms of features such as ( \pm human), ( \pm gender), ( \pm adulthood), called semes or classemes by some structuralists 
(Hjelmslev 1959; Coseriu 1973; Pottier 1974). However, how would one distinguish between, say, heifer-vs.-mare? Which distinctive feature triggers the opposition, ( \pm bovine) or ( \pm equine)? There is really no way to establish which one is conceptually the trigger. To put it in more technical structuralist terms, it is difficult to determine which one is marked and which one is unmarked - a problem that will be taken up below.

Moreover, a vast array of distinctive features would be needed to make distinctions of this kind in the first place (Schooneveld 1978), rendering the whole analytical exercise logically impracticable. The alternative may be to decide on a small axiomatic set of semes that cut across languages and are thus considered to be universal. Research on identifying such a set is ongoing, but it has yet to yield a set of features that may explain all kinds of conceptual oppositions (see, for example, the perceptive work of Wierzbicka 1996, 1997, 1999, 2003).

However, one should realize that unlike phonological and grammatical systems, which are closed form-based systems, conceptual systems are open-ended and, thus, difficult to pin down to a finite set of distinctive values. This conclusion has been reached in a study of antonyms where Paradis, Willners and Jones suggest that "antonymy has conceptual basis and meanings are negotiated in the context where they occur" (Paradis et al. 2009: 381).

The Prague School linguists soon came to realize that binary oppositions were not the only ones to characterize codes. They found various degrees of oppositional structure in various codes (Pos 1938; Jakobson 1939; Trubetzkoy 1939; Martinet 1960). Thus, oppositions can be strictly binary (right-vs.-left), ternary (past-present-future), four-part (addition-subtraction-multiplication-division), and so on. The type of opposition that emerges in a system depends on the system itself.

The anthropologist Claude Lévi-Strauss (1958), for example, showed that pairs of oppositions often cohered into sets forming recognizable units within specific cultural codes or systems. In a similar train of thought, Greimas $(1966,1970,1987)$ introduced the notion of the semiotic square - a model of opposition involving two sets of concepts forming a square arrangement. In effect, by extending opposition theory, it has become obvious that its relevance to the study of semiosis and representation is as pivotal today as it was when Saussure and the early structuralists put it forward.

\section{Metaphors and metaphor identification}

Denotation is the literal sense of a word, and connotation, its extended meaning. For instance, in the word pair 'sweet bananas', the word 'sweet' is used in the literal sense while in the word pair 'sweet babies' it is used in its extended meaning. In fact, adjective-noun connotations such as those instantiated by 'sweet babies' are considered as 
metaphors and as a specific type of noun-based metaphors known as Type III metaphors (Krishnakumaran, Zhu 2007).

From a wider theoretical perspective, the prevalence of metaphors in human thinking and language (Lakoff, Johnson 1980, 1999) and the way they provide a context for human reasoning have turned them into a major object of research not only in cognitive linguistics and psychology (Gibbs et al. 2004; Kintsch 2000; Thibodeau, Boroditsky 2011) but in natural language processing too (Assaf et al. 2013; Birke, Sarkar 2007; Krishnakumaran, Zhu 2007; Neuman et al. 2013; Neuman et al. In press; Turney et al. 2011).

While human beings naturally process metaphors, replicating this human ability to detect and perceive metaphors in silico is far from trivial. The first task facing an intelligent system in comprehending a metaphorical expression, or more accurately an utterance suspected to be metaphorical, is to identify it as such. In other words, metaphor identification is the first phase in processing a metaphor. Indeed, one of the main challenges in Natural Language Processing (NLP) is metaphor identification.

Despite the alleged simplicity of this task, years of intensive research have shown limited results and the models designed for metaphor comprehension were not able to successfully simulate human intelligence. As argued quite recently by Veale (2011: 278; our emphasis) “... while computationally interesting, none (of these models) has yet achieved the scalability or robustness needed to make a significant practical impact outside the laboratory." However, recent cognitively motivated algorithms (Turney et al. 2011; Assaf et al. 2013; Neuman et al. 2013) have shown that metaphor identification is feasible and may have important consequences for natural language understanding.

For addressing the challenge of metaphor identification through opposition theory, we focus on one type of metaphor. Following Krishnakumaran and Zhu's approach (cf. Krishnakumaran, Zhu 2007), we restrict the scope of this paper to metaphoric usages involving nouns and to adjective-noun metaphors only. We focus on this type of metaphor as recent advances in natural language processing (Turney et al. 2011; Assaf et al. 2013) have led to significant advancements in identifying this type of metaphor and to high correlation with human performance.

The decision to focus our efforts on the identification of adjective-noun metaphors clearly limits the scope of the current study. Therefore, the current study does not pretend to cover the whole spectrum of metaphorical language-use or even the whole spectrum of adjective-noun metaphors.

There have been several strategies for metaphor identification (Birke, Sarkar 2007; Krishnakumaran, Zhu 2007; Turney et al. 2011). Most of these methods demand heavy computational resources as they rely on computationally demanding processes such as Word Sense Disambiguation (Navigeli 2009). In addition, none of these models/ algorithms involved opposition theory as a guiding theory. In the next section we 
introduce a simple and computationally economic model of Type III metaphor identification and present an algorithm that instantiates this model.

\section{The model and the algorithm}

Our model is simple; in addition to opposition theory it draws on several converging ideas from cognitive sciences and linguistics. First, we use the notion of markedness pointing to the asymmetry between elements of linguistic and conceptual structures. As argued by Haspelmath (2006), "The term 'markedness' is superfluous, because some of the concepts that it denotes are not helpful, and others are better expressed by more straightforward, less ambiguous terms." Here we adhere to a very general sense of markedness as asymmetry between the adjective modifying the noun in a target word pair (e.g., 'high standards') and its antonym.

It is important to realize that the adjective modifying the noun in an adjectivenoun pair is a conceptual category: 'sweet' is a category; 'hard' is a category; 'dark' is a category, and so on.

As argued by Harnad (2005), most cognition is the acquisition of categories and at the heart of adaptive cognition and behaviour is doing the right things with categories. In this context, Harnad (1982) suggests that a metaphor constitutes an apposition, the collation of two embodied traces of experience analogues of the experience.

This suggestion is in line with the selectional preference approach (Light, Greiff 2002) to metaphor identification (Wilks 1975), suggesting that metaphorical language-use involves some kind of violation of literal use. For instance, the phrase 'sweet baby' is metaphorical as 'sweet' is an embodied category basically applicable to objects we can taste. That is, objects belonging to the FOOD category. A 'sweet baby' is therefore a violation of 'sweet' selectional preference as 'baby' does not belong to the preferred FOOD category. In this context, judging whether an adjective-noun phrase is metaphorical may use the conceptual opposition of the adjective linguistically expressed as its antonym. The fact that 'sweet baby' may be considered as a "dead metaphor" is of no relevance to our case. While teaching computers to identify metaphors we may insert a whole dictionary to the machine, a dictionary stating explicitly that a certain phrase is metaphorical, or may provide it with a general algorithm to do it by itself. Here we follow a more general and flexible approach of introducing a metaphor identification model that identifies metaphors regardless of them being "dead" or "alive".

In the context of adjective-noun metaphors, we must emphasize as Harnad (personal correspondence Feb. 2013) suggests that there is a crucial difference between the digital binary nature of object categories and the analogue continuous nature of property categories. For instance, 'living' versus 'non-living' is categorical while 'sweet' is relative 
and context dependent. Harnad (2013) also suggests that metaphor is evident when a similarity judgment (i.e., this resembles that) is somehow treated as or becomes a categorization.

It was shown that antonymy, which is the expression of opposition in the lexicon, has a conceptual basis and that antonyms may be conceptually distinguished in terms of binary oppositions (Paradis et al. 2009). If there is an asymmetry between the adjective modifying a given noun and its antonym representing its conceptual binary opposition, then in cases of metaphorical language-use the antonym of the adjective should be semantically related to a lesser extent with the noun its opposing adjective modifies. In other words, the markedness of the adjective, the conceptual asymmetry it has with its opposing conceptual category, may be used for metaphor identification!

Here we present our research hypothesis. In a case of literal language-use, we should expect that the adjective and its major antonym are both conceptual categories that modify the noun's category to a similar extent. By 'modify' we mean that they have informational value. For instance, some things in the world are sweet. Some sweet objects belong to the FOOD category in which CAKE is a subcategory/member, and their intersection is 'sweet cake'.

The antonym of 'sweet' can be 'bitter'. In this case, 'bitter' is associated with CAKE too because FOOD, which is the super-ordinate category of CAKE, can be bitter. This is not the case with metaphorical language-use. For instance, let us compare the word pair 'bitter relations' to the word pair 'bitter chocolate'. In the case of the literal pair (i.e., bitter chocolate) it is highly reasonable that the antonym of 'bitter' - 'sweet' - will be associated with 'chocolate' to a larger extent than it is associated with 'relations'.

In sum, our model hypothesizes that in cases of literal use, we should expect a higher level of symmetry between the adjective and its antonym in the sense that both of them are semantically related modifiers of the noun. In contrast, in a case of metaphorical language-use we should expect asymmetry because the metaphorical use violates the 'selectional preference' of the adjective, which means that certain embodied categories of experience are less likely to modify other categories.

Based on this simple theorization, we empirically measured the semantic similarity between the antonym of a given adjective and the noun modified by the adjective in the word pair, and used the outcome of this measurement process in order to predict whether the word pair is metaphorical or literal.

In this context, it must be emphasized that our model is applicable only to cases where the adjective has a clear antonym. Therefore, we have no pretensions to cover the whole spectrum of metaphor identification and not even the whole spectrum of adjective-noun metaphors.

Our model/algorithm is straightforward. Given a word pair we first identify the antonym of the adjective and second we measure the semantic similarity between the 
antonym and the noun modified by the original adjective. To measure the similarity between the antonym and the target noun we used the state-of-the-art knowledge in computational semantics and measured the similarity through a vector space model of semantics (Turney, Pantel 2010). More specifically we draw on a term-to-context similarity matrix developed by Turney et al. 2011. This matrix allows us to measure the semantic similarity between two terms (e.g., 'bitter' and 'baby') by calculating the cosine between the rows of the matrix. The only relevant variable for predicting whether the phrase is metaphorical is the similarity between the antonym and the noun. To test this algorithm we used the dataset described in the next section.

\section{The dataset}

Our model/hypothesis has been tested on a dataset developed by Turney et al. 2011. For their experiment, Turney et al. 2011 used five adjectives: 'dark', 'deep', 'hard', 'sweet', and 'warm. This dataset is limited to five adjectives only and therefore we are very cautious in generalizing our results. However, Turney et al.'s 2011 paper was presented at one of the most competitive conferences in the field of NLP (EMNLP), and as such the dataset is qualified as a satisfactory benchmark for comparison. In addition, since the resources allocated to the current study were limited, we settled for a limited dataset as a "proof-of-concept" only. In a future study, we plan to test our model on a larger dataset.

For each of the adjectives, Turney et al. 2011 composed twenty word pairs in which the first word is the adjective and the second word is a noun. These pairs were identified through the Corpus of Contemporary American English (COCA) (Davies 2009), which is the most representative corpus of American English, and by seeking the nouns that follow each adjective in the corpus and sorting the candidate adjective-noun pairs by frequency. Turney et al. 2011 required minimum mutual information (MI) of 3 between the adjective and the noun in order to assure that the noun is statistically significantly collocated with the adjective. The decision to use a minimal MI of 3 is based on the corpus norms. In some of the test pairs, the adjective was used in a metaphorical sense (e.g., 'dark thoughts') and in the rest in a literal sense (e.g., 'dark skin'). Five judges, undergraduate students in psychology, were asked to judge whether the use of the adjective is literal or metaphorical and reached a high level of interjudge reliability (Cronbach's alpha $=.95)$. Concrete-Abstract, which is the algorithm developed by Turney et al. 2011, was able to predict the judges' average rating with $79 \%$ accuracy. 


\section{Analysis and results}

Our algorithm uses only one variable in order to predict whether the pair is metaphorical or not - the similarity of the adjective's antonym with the target noun. For identifying the antonyms, we used the Oxford English Dictionary to identify the first antonym of each of our five adjectives.

In Turney et al.'s 2011 dataset, 44 of the pairs are metaphorical and the other 56 literal. Therefore, the baseline for prediction is 56\%. We used Binary Logistic Regression Analysis as our statistical model. Binary Logistic Regression is a type of probabilistic classification model where the dependent variable is a binary dichotomous variable with two values only. We used this model in order to measure our ability to classify the adjective-noun phrases into two categories: metaphorical and literal, based on the independent continuous variable that is the similarity of the adjective's antonym with the target noun.

Using a Binary Logistic Regression with the antonym's similarity as the independent variable and the word pair type as a criterion $(0=$ literal pair, $1=$ metaphorical pair $)$, produced statistically significant results $(\chi 2=77.36, p<.001)$ with $89 \%$ accuracy. This means that in $89 \%$ of the cases in our dataset our algorithm was able to classify a word pair correctly as metaphorical or literal. In other words, in $89 \%$ of the word pairs our algorithm has automatically reached a decision that is in agreement with the decision reached by the human judges in Turney et al.'s 2011 study. The precision was $88 \%$, which means that when predicting that a phrase (e.g., 'dark hair') is metaphorical our algorithm was correct in $88 \%$ of the cases. The recall was $86 \%$, which means that our algorithm correctly identified $86 \%$ of the metaphorical pairs in the dataset.

\section{Discussion}

Under the influence of Chomsky, modern linguistics, specifically in the United States, has been demarcating a sharp line between language as an abstract mathematical structure, and human cognitive processes rich in semantics. Along a similar line, modern cognition inspired by early computational models considered language to be a realm categorically differentiated from linguistic semantic processes. This sharp divide is evident in discussions of the so-called Sapir-Whorf hypothesis. However, recently there has been accumulating evidence that the sharp line portrayed between 'language' and 'thought', to use Vygotsky's original terminology, is a false one. It was not only shown that language is deeply conflated with thought processes such as abstraction (Neuman et al. 2012) and even provides an interpretive context for emotion recognition (Barrett et al. 2007) but that the meaning of words, considered by Vygotsky as the meeting point of thought and language, is deeply embodied in neural processes (Just et al. 2010; Binder, Desai 2011). 
These findings necessarily enact old ideas from semiotics, the study of signs and signification (Danesi 2007) as the major semiotic theories such as those of Saussure, Vygotsky, and Peirce not only understand the conflation of language and thought but deeply recognize their embodied base. In this context, the current paper may be considered to be one instance only in a possible new line of research where the semiotic umbrella is used for generating new hypotheses and testing them in silico by using current tools of computational semantics.

The model/algorithm has three clear benefits. First, it is clearly guided by theorization originating from semiotics. In this sense, the algorithm is not an engineering project evaluated through performance only but a venture theoretically firmly grounded in ideas from linguistics, semiotics, and psychology.

The second benefit is that in computational terms the model/algorithm is highly economic. It does not need heavy computational resources, but only minimal cognitivelinguistic resources evident in human behaviour.

The third pragmatic benefit is that the model/algorithm produces significant results. Being tested against the Concrete-Abstract algorithm, argued to be the "state-of-the-art", our model has improved the accuracy of classification by ten percent, which is not only a statistically significant improvement $(p<.001)$, but a significant improvement from any common-sensical point of view. Despite the benefits of the model/algorithm it is a first step only and throughout the paper we have been pointing at our modest and limited aim. The model is restricted to cases where antonyms exist for the adjective in the adjective-noun pair and it has been tested on a small and limited set of adjectives. We plan to extend the model/algorithm to other types of metaphors as well and to examine further its implications for examining and refining opposition theor $y^{2}$.

\section{References}

Andersen, Henning 1989. Markedness theory: The first 150 years. In: Tomic, Olga Miseska (ed.), Markedness in Synchrony and Diachrony. Berlin: Mouton de Gruyter, 11-16.

- 2001. Markedness and the theory of linguistic change. In: Andersen, Henning (ed.), Actualization. Amsterdam: John Benjamins, 19-57.

- 2008. Naturalness and markedness. In: Wellems, Klaas; De Cuypere, Ludovic (eds.), Naturalness and Iconicity in Language. Amsterdam: John Benjamins, 101-119.

Andrews, Edna 2003. Conversations with Lotman: Cultural Semiotics in Language, Literature, and Cognition. Toronto: University of Toronto Press.

Assaf, Dan, et al. 2013. Why "dark thoughts" aren't really dark: A novel algorithm for metaphor identification. Paper presented at the IEEE Comp. Intel. Conf. Singapore, 2013.

2 The authors would like to thank Peter Turney for his permission to use the similarity matrix, Stevan Harnad for his constructive reading of the paper, and the anonymous reviewers for their helpful comments. 
Barbaresi, Lavinia Merlini 1988. Markedness in English Discourse: A Semiotic Approach. Parma: Edizioni Zara.

Barrett, Lisa Feldman; Lindquist, Kristen; Gendron, Maria 2007. Language as context for the perception of emotion. Trends in Cognitive Science 11: 327-332.

Belardi, Walter 1970. Lopposizione privativa. Napoli: Istituto Universitario Orientale di Napoli.

Binder, Jeffrey; Desai, Rutvik 2011. The neurobiology of semantic memory. Trends in Cognitive Science 15: 527-536.

Birke, Julia; Sarkar, Anoop 2007. Active learning for the identification of nonliteral language. In: Proceedings of the Workshop on Computational Approaches to Figurative Language, HLT/ NAACL-07, 21-28.

Blanché, Robert 1966. Structures intellectuelles. Paris: Vrin.

Bolinger, Dwight 1968. Aspects of Language. New York: Harcourt, Brace, Jovanovich.

Chomsky, Noam; Halle, Morris 1968. The Sound Pattern of English. New York: Harper \& Row.

Coseriu, Eugenio 1973. Probleme der strukturellen Semantik. [Tübinger Beiträge zur Linguistik 40.] Tübingen: Gunter Narr Verlag.

Danesi, Marcel 2007. The Quest for Meaning: A Guide to Theory and Practice in Semiotics. Toronto: University of Toronto Press.

Davies, Mark 2009. The 385+ million word Corpus of Contemporary American English (19902008+): Design, architecture, and linguistic insights. International Journal of Corpus Linguistics 14: 159-190.

Derrida, Jacques 1967. De la grammatologie. Paris: Minuit.

Elšík, Viktor; Matras, Yaron 2006. Markedness and Language Change: The Romani Sample. Berlin: Mouton de Gruyter.

Fox, James J. 1974. Our ancestors spoke in pairs: Rotinese views of language, dialect and code. In: Bauman, Richard; Scherzer, Joel (eds.), Explorations in the Ethnography of Speaking. Cambridge: Cambridge University Press, 65-88.

- 1975 . On binary bategories and primary symbols. In: Willis, Roy G. (ed.), The Interpretation of Symbolism. London: Malaby, 99-132.

Gibbs, Raymond. W.; Costa Lima, Paula Lenz; Francozo, Edson 2004. Metaphor is grounded in embodied experience. Journal of Pragmatics 36: 1189-1210.

Godel, Robert 1957. Les sources manuscrites du "Cours de linguistique générale" de F. de Saussure. Paris: Minard.

Greimas, Algirdas Julien 1966. Sémantique structurale. Paris: Larousse.

- 1970. Du sens. Paris: Seuil.

- 1987. On Meaning: Selected Essays in Semiotic Theory. [Perron, Paul J.; Collins, Frank H., trans.] Minneapolis: University of Minnesota Press.

Harnad, Stevan 1982. Metaphor and mental duality. In: Simon, Thomas W.; Scholes, Robert J. (eds.), Language, Mind and Brain. Hillsdale: Erlbaum, 189-211.

- 2005. To cognize is to categorize: Cognition is categorization. In. Cohen, Henri; Lefebvre, Claire (eds.), Handbook of Categorization in Cognitive Science. Amsterdam etc.: Elsevier, 20-43.

Haspelmath, Martin 2006. Against markedness (and what to replace it with). Journal of Linguistics 42: 25-70.

Hjelmslev, Louis 1939. Note sur les oppositions supprimables. Travaux de Cercle Linguistique de Prague 8: 51-57.

- 1959. Essais linguistique. Copenhagen: Munksgaard. 
Ivanov, Vjačeslav 1974. On antisymmetrical and asymmetrical relations in natural languages and other semiotic systems. Linguistics 119: 35-40.

Jakobson, Roman 1939. Observations sur le classement phonologique des consonnes. Proceedings of the Third International Congress of Phonetic Sciences, Ghent 1938, 34-41.

Jakobson, Roman; Karcevskij, Sergej; Trubetzkoy, Nikolai 1928. Proposition au premier congrès international des linguistes: Quelles sont les méthodes les mieux appropriées à un exposé complet et pratique de la phonologie d'une langue quelconque? Premier Congrès International des Linguistes à la Haye. Leiden: A. W. Sijthoff, 36-39.

Just, Marcel Adam; Cherkassky, Vladimir L.; Aryal, Sandesh; Mitchell, Tom M. 2010. A neurosemantic theory of concrete noun representation based on the underlying brain codes. PLoS ONE, 5(1), e8622. doi:10.1371/journal.pone.0008622.

Kintsch, Walter 2000. Metaphor comprehension: A computational theory. Psychonomic Bulletin \& Review 7: 257-266.

Krishnakumaran, Saisuresh; Zhu, Xiaojin 2007. Hunting elusive metaphors using lexical resources. In: Proceedings of the Workshop on Computational Approaches to Figurative Language (FigLanguages '07). Stroudsburg: Association for Computational Linguistics, 13-20.

Lakoff, George; Johnson, Mark 1980. Metaphors We Live By. Chicago: Chicago University Press.

- 1999. Philosophy in the Flesh: The Embodied Mind and Its Challenge to Western Thought. New York: Basic.

Lepik, Peet 2008. Universals in the Context of Juri Lotman's Semiotics. Tartu: Tartu University Press. Lévi-Strauss, Claude 1958. Anthropologie structurale. Paris: Plon.

- 1971. L’Homme nu. Paris: Plon.

Light, Mark; Greiff, Warren. 2002 Statistical models for the induction and use of selectional preferences. Cognitive Science 26(3): 269-281.

Lorrain, François 1975. Réseaux sociaux et classifications sociales. Paris: Hermann.

Lotman, Juri 1991. Universe of the Mind: A Semiotic Theory of Culture. [Shukman, Ann, trans.; Eco, Umberto, intr.] Bloomington: Indiana University Press.

Martinet, André 1960. Éléments de linguistique générale. Paris: Colin.

McCarthy, John J. 2001. A Thematic Guide to Optimality Theory. Cambridge: Cambridge University Press.

Mel’čuk, Igor 2001. Linguistic Theory: Communicative Organization in Natural Language. Amsterdam: John Benjamins.

Mettinger, Arthur 1994. Aspects of Semantic Opposition in English. Oxford: Oxford University Press.

Navigli, Roberto 2009. Word sense disambiguation: A survey. ACM Computing Surveys 41(2): 1-69.

Needham, Rodney 1973. Right and Left. Chicago: University of Chicago Press.

Neuman, Yair et al. (in press). How do we understand the meaning of connotations? A cognitivecomputational model. Semiotica.

Neuman, Yair; Assaf, Dan, Cohen, Yohai, Last, Mark, Argamon, Shlomo, Howard, Newton, \& Frieder Ophir 2013. Metaphor identification in large texts corpora. PLoS ONE 8(4): e62343. doi:10.1371/journal.pone.0062343.

Neuman, Yair; Turney, Peter; Cohen, Yohai 2012. How language enables abstraction: A case study in computational cultural psychology. Integrative Psychological and Behavioral Sciences 46: 129-145.

Ogden, Charles Kay 1932. Opposition: A Linguistic and Psychological Analysis. London: Paul, Trench, and Trubner. 
Ogden, Charles Kay; Richards, Ivor Armstrong 1923. The Meaning of Meaning: A Study of the Influence of Language upon Thought and of the Science of Symbolism. London: Routledge and Kegan Paul.

Paradis, Caritha; Willners, Caroline; Jones, Steven 2009. Good and bad opposites: Using textual and experimental techniques to measure antonym canonicity. The Mental Lexicon 4: 380-429.

Parsons, Talcott; Bales, Robert Freed 1955. Family, Socialization, and Interaction Process. Glencoe: Free Press.

Pos, Hendrik J. 1938. La notion d’opposition en linguistique. Xle Congrès International de Psychologie, 246-247.

Pottier, Bernard 1974. Linguistique générale. Paris: Klincksieck.

Saussure, Ferdinand de. 1916. Cours de linguistique générale. [Bally, Charles; Sechehaye, Albert, eds.] Paris: Payot.

Schooneveld, Cornelis H. van. 1978. Semantic Transmutations. Bloomington: Physsardt.

Shutova, Ekaterina 2010. Models of metaphor in NLP. In: Proceedings of the 48th Annual Meeting of the Association for Computational Linguistics, Uppsala, Sweden, July 11-16, 688-697.

Thibodeau, Paul H.; Boroditsky, Lera 2011. Metaphors we think with: The role of metaphor in reasoning. PLoS ONE, 6(2), E16782. doi:10.1371/journal.pone.0016782

Tomic, Olga Mišeska (ed.). 1989. Markedness in Synchrony and Diachrony. Berlin: Mouton de Gruyter.

Trubetzkoy, Nikolaĭ 1939. Grundzüge der Phonologie. Travaux du Cercle Linguistique de Prague 7.

Turney, Peter D.; Pantel, Patrick 2010, From frequency to meaning: Vector space models of semantics. Journal of Artificial Intelligence Research (JAIR) 37: 141-188.

Turney, Peter D., Neuman, Yair, Assaf, Dan, Cohen, Yohai 2011. Literal and metaphorical sense identification through concrete and abstract context. In: Proceedings of the 2011 Conference on Empirical Methods in Natural Language Processing, Edinburgh, Scotland, UK, July 27-31, 680-690.

Veale, Tony 2011. Creative language retrieval: A robust hybrid information retrieval and linguistic creativity. In: Proceedings of the 49th Annual Meeting of the Association for Computational Linguistics, Portland, Oregon, June 19-24, 2011, 278-287.

Wallon, Henri 1945. Les origines de la pensée chez l'enfant. Vol. 1. Paris: Presses Universitaires de France.

Wierzbicka, Anna 1996. Semantics: Primes and Universals. Oxford: Oxford University Press.

- 1997. Understanding Cultures through their Key Words. Oxford: Oxford University Press.

- 1999. Emotions Across Languages and Cultures: Diversity and Universals. Cambridge: Cambridge University Press.

- 2003. Cross-Cultural Pragmatics: The Semantics of Human Interaction. New York: Mouton de Gruyter.

Wilks, Yorick 1975. A preferential pattern-seeking semantics for natural language inference. Artificial Intelligence 6: 53-74. 


\section{Теория оппозиций и вычислительная семиотика}

Теория оппозиций утверждает, что основой главных когнитивных и лингвистических процессов являются бинарные оппозиции (например, «высокий/низкий»). Однако теория оппозиций не находила применения в вычислительных когнитивно-семиотических моделях. В данной статье предлагается простая модель опознания метафор, которая основывается на теории оппозиций. Алгоритм, основанный на этой модели, был протестирован на материале из 100 фраз, содержащих пары «прилагательное-существительное». Примерно половина из них метафоры (например, «черные мысли»), остальные употребляются в прямом значении (например, «черные волосы»). С помощью алгоритма метафоры были опознаны с точностью 89\%, что иллюстрирует продуктивность применения теории оппозиций в моделировании опознания метафор.

\section{Opositsiooniteooria ja arvutussemiootika}

Opositsiooniteooria väidab, et kognitiivsete ja lingvistiliste põhiprotsesside aluseks on binaarsed opositsioonid (nt kõrge - madal). Samas pole opositsiooniteooriat rakendatud komputatsioonilistes kognitiiv-semiootilistes mudelites. Käesolevas artiklis pakume välja lihtsa metafoorituvastusmudeli, mis toetub opositsiooniteooriale. Mudelit näitlikustavat algoritmi testiti 100 fraasist koosneval andmekogumil, mis sisaldab omadussõnanimisõna paare, millest ligikaudu pooled esindavad metafoorset keelekasutust (nt 'mustad mõtted') ja ülejäänud sõna-sõnalist keelekasutust (nt 'mustad juuksed'). Algoritmi abil tuvastati metafoorid $89 \%$ täpsusega ning see illustreerib opositsiooniteooria olulisust metafooritöötluse modelleerimises. 